\title{
The Effect of Visionary Leadership Characteristics on Organizational Agility in Health Organizations; An Application in Private Hospitals in Bakirkoy District of Istanbul Province
}

\author{
Gülay TAMER*
}

\begin{abstract}
In this study, a field research was conducted to determine the effect of visionary leadership on organizational agility. The data of the analysis were obtained from the health care workers working in private hospitals in the Bakirkoy region by the survey method and 200 questionnaires were analyzed statistically. To achieve the results, reliability analysis, correlation analysis and regression analysis were performed. In the conclusion part, it is confirmed that there is a parallel and meaningful relationship between the visionary leader's behavior and organizational agility.
\end{abstract} Bakirkoy

Keywords: Visionary Leadership, Organization, Agility, Private hospital,

\section{Sağlık Örgütlerindeki Vizyoner Liderlik Özelliklerinin Örgütsel Çeviklik Üzerine Etkisi; İstanbul İli Bakırköy İlçesindeki Özel Hastanelerde Bir Uygulama}

Öz

Bu çalışmada, vizyoner liderliğin örgütsel çeviklik üzerindeki etkisini belirlemek amacıyla bir alan araștırması yapılmıştır. Analizin verileri Bakırköy bölgesindeki özel hastanelerde çalışan sağlık çalışanlarından anket yöntemi ile elde edilmiş olup 200 anket formu istatistiksel olarak analiz edilmiștir. Araştırmada, vizyoner liderliği ve örgütsel çeviklik hakkında temel açıklamalar yapılmıştır. Sonuca ulaşmak için güvenilirlik analizi, korelasyon analizi ve regresyon analizi yapılmıștır. Sonuç bölümünde, vizyoner liderin davranışı ile örgütsel çeviklik arasında paralel ve anlamlı bir ilişki olduğu doğrulanmıştır. Bakırköy

Anahtar Kelimeler: Vizyoner, Liderlik, Organizasyon, Çeviklik, Özel Hastane,

\section{Introduction}

The first approach developed on the subject of leadership is the theory of properties. This type of approach is considered to be the most important factor in determining the effectiveness of the leadership process of the characteristics of the leader (Nobarieidishe, 2018, p.199). In other words, the characteristics that the leader has affect the person being a leader and managing the group within a particular group (Triaa et al.

\section{Özgün Araştırma Makalesi (Original Research Article)}

Geliş/Received: 17.12.2019

Kabul/Accepted: 25.01.2021

DOI: https://dx.doi.org/10.17336/igusbd.655890

* Asst. Prof. Dr., Istanbul Gelisim University, Faculty of Health Sciences, Istanbul, Turkey,

E-mail: gtamer@gelisim.edu.tr ORCID https://orcid.org/0000-0002-7897-1603 
2018). The leader is a different person from the other group members in terms of their characteristics. According to this theory, a person must have different characteristics in order to be a leader. So the focus of this theory is to find out who has the characteristics among the group members that distinguish successful leaders from failing (Cloud and Uygun, 2010). According to the theory of properties, people are born leaders, and they cannot be leaders later. It is distinguished from the others by the characteristics of the person (Koçel, 2015).

In today's global competitive environment, many new leadership approaches have been proposed to increase the effectiveness of organizations. The changing environment conditions contributed to the emergence of these approaches, as well as the changing human perception level and understanding capacity (Chan, 2017). People with a more competent and libertarian worldview have started to push the stereotypes of government that restrict and shape themselves, and as a result of such developments, it has become necessary to reconsider and approach leadership approaches (Çağlar, 2004, p.97). Some leadership approaches developed in the field of leadership in recent years are briefly summarized below:

\section{Visionary Leadership}

One of the many modern leadership issues that emerged after the 1990s is visionary leadership. Visionary leadership is a leadership issue that is of great importance and is of great importance in businesses, especially after its emergence. In order to better understand this concept of leadership, the word vision, which is one of the name stakeholders, will first be emphasized (Michael and Treviño, 2006).

Vision is a harbinger of the desired future. It is the position that one wants to be in the future from today. Vision is an effort to capture the reality of the future based on the current reality and the process of sharing. In other words, vision is the path or plan to achieve an activity, action, guide, or goal. Vision is the desired picture of the future created at the moment and is a dream of the future (Bender, 2006, p.109).

Vision in the organizational sense; to be able to design, develop and share a dreamed future for the organization. Vision serves as a roadmap for organizations in an accelerated process of change and uncertainties. Vision allows leaders to go beyond everyday issues and to draw a framework for the future. To be able to design, develop, share, risk and balance the target to be achieved in terms of reality (Karaman, 2006).

The word vision is the cornerstone of visionary leadership. There are some features that need to be a good vision. These features should make the organization attractive, energize people, give meaning to the lives of employees, have a standard of excellence, and act as a bridge connecting the past and the future (Nanus, 1992).

It has the determination and belief in achieving the organizational objectives it determines. They create a shared organizational culture, they are creative, and they dream of a better future for the organization. Visionary leaders motivate employees with vision. The organization is the master of vision and enables employees to focus on future organizational objectives. In doing so, visionary leaders must listen to their employees, be open to communication, respect others and value their opinions (Quigley, 1998, pp.279280). To put it briefly, visionary leaders are able to create high motivation, working with them, creating a picture of the future by acting with their employees on the path that can lead to success. They are the ones who bring their employees to the best level of performance, create a strong organizational culture and spread it throughout the organization, and are aware of the change and development required in implementing all of these (Longman, 1991). 
Visionary Leaders develop leadership styles inspired by what a business can be. They do not overwhelm technical details and guide their followers in the fields of development and innovation. The leaders who adopt this style steer the whole organization to wider horizons by purging their organization from the uncertainty of time and encouraging the common success of the union (Ugurlu, et. al, 2015). For example, if you're in If a visionary leader is sought for leadership and guidance, the business is either experiencing a transformation process or going through difficult times (Tetik, Akkaya, 2018). By their very nature, visionary leaders awaken the spirit of unity and lead the organization towards the set goals. Visionary leaders are charismatic and determined to achieve their goals. They identify themselves as reliable coaches who can bring the organization to calm shores during difficult times or transformation (Chan, 2017, pp: 486499).

\section{Organizational Agility \\ 2.1. Concept of Organizational Agility}

The concept of organizational agility is the rapid adaptation of enterprises to sudden, unpredictable changes in environmental and intrinsic factors, and the success of survival in changing environmental conditions to reorganize in line with new developments and maintaining sustainability in profitability as well (Goldman,1995).

The concept of organizational agility has been used in sectors such as production, manufacturing and technology since the beginning of the nineties, and the model, definition and components created for this concept have been used. The concept in question has been the subject of numerous studies (Chan, et al. 2017). Before examining the organizational agility model, the main component is the definition of the agility model; Agility is the key to the success of companies that redefine and continuously improve their value by making changes to their product, service networks and market (Tanrıbil, 2015). Agile companies constantly perceive opportunities to compete in their product markets and combine the knowledge and mobility needed to achieve these opportunities (Sambamurthy et al. 2003, pp. 237-263). Agility can detect changes (opportunities, threats, or a combination of the two) around an organization, and focus on customers, shareholders by reorganizing their resources, processes and strategies, and responding quickly to this (Ganguly et.al, 2009, pp. 410-423). Agility is not only about getting used to changes, but also to re-establish company structures, organizational systems, technology, facilities and staff to take advantage of unexpected and possibly short-term market opportunities. Ergo, it is an adaptation ability achieved by structuring and shaping (Triaa, et al. 2018). It does not include a transition from one place to another, but a complete change and cooperation (Arslan, 2007, pp.57-70). In this context, as can be seen from the definitions of agility, in today's unpredictable and competitive business world, it is imperative that firms have different competitive characteristics in order to compete, otherwise they will move towards extinction. One of these features that today needs in turbulent market environments is agility (Buharlıoğlu, 2014). 


\subsection{Organizational Agility Capabilities}

Some researchers have tried to define the concept of organizational agility based on their domain practices and context. They proposed different conceptual models to determine the characteristics of organizational agility (Chamanifard, et al., 2018). To describe the basic dimensions, characteristics and qualities of an agile organization, some of these propositions are stated as follows:

Sherehiy and colleagues, the global characteristics of agility applicable to all areas of a business, flexibility, responsiveness, speed, culture of change, integration and low complexity, high quality, personalized product and self-capabilities (Sherehiy et al., 2007, pp.445-460).

Some of the best-known conceptualizations have been made by researchers who have developed four key organizational agility dimensions to master change and remain competitive.

\subsection{Benefits and Requirements of Organizational Agility}

At the beginning of the 21st century, the world was remarkably transformed in many ways, especially through channels of communication. These changes require organizations to review their strategic priorities and visions. Sharifi \& Zhang is one of the ways in which organizational agility responds to these changes and the factors of the era (Sharifi, Zhang 1999, pp.7-22). Organizational Agility plays an important role in the organization's life because it uses new technology to provide staff with knowledge, high skills, restructuring and organizational processes (Tanrıbil, 2015).

\section{An Implementaion in Health Sector on the Effect of Visionary Leadership on Organizational Efficiency \\ 3.1. Subject and Scope of the Research}

The subject of the research is to create a comprehensive model of visionary leadership concept that affects organizational agility by taking dependent variable. The research will be carried out within the framework of the mentioned model (Akkaya and Tabak 2018). The model will be examined, tested and evaluated within the scope of survey data received from employees in Private Hospitals in Bakirkoy District.

\subsection{Purpose of Research}

In the research base received it has four objectives: In line with descriptive statistics, to determine the visionary leadership level and organizational agility level of the managers working in hospitals in Bakirkoy, to examine the relationship between subdimensions of visionary leadership and sub-dimensions of organizational agility, Examine whether visionary leadership has an impact on organizational agility, and if so, determine the level of influence, to examine the impact of visionary leadership sub-dimensions on organizational agility capabilities (speed, response time, competence and flexibility). 
Table-1: KMO Coefficient and Bartlett Sphericity Test for the Visionary Leadership Scale

\begin{tabular}{|l|l|}
\hline $\begin{array}{l}\text { Kaiser-Meyer-Olkin (KMO) } \\
\text { Measurement of Sampling Adequacy. }\end{array}$ & .858 \\
\hline Bartlett Sphericity Test Degree of Freedom & $\begin{array}{l}1374.908 \\
91\end{array}$ \\
\hline Chi-square Statistics (Significance) & 000 \\
\hline Cronbach's $\alpha$ value of the scale & 935 \\
\hline Cronbach's $\alpha$ for the Visionary Thought dimension of the scale & 910 \\
\hline Cronbach's $\alpha$ value for the scale to be Action Oriented & 817 \\
\hline Cronbach's $\alpha$ value for the official dimension of the scale &, 841 \\
\hline Cronbach's $\alpha$ value for the dimension of the scale &, 826 \\
\hline
\end{tabular}

Table-2: KMO Coefficient and Bartlett Sphericity Test for Organizational Agility Scale

\begin{tabular}{|l|l|}
\hline $\begin{array}{l}\text { Kaiser-Meyer-Olkin (KMO) } \\
\text { Measurement of Sampling Adequacy. }\end{array}$ & .927 \\
\hline Bartlett Sphericity Test Degree of Freedom & $\begin{array}{l}1605.691 \\
55\end{array}$ \\
\hline Chi-square Statistics (Significance) & 000 \\
\hline Cronbach's $\alpha$ value of the scale & 930 \\
\hline Cronbach's $\alpha$ value for the Competence dimension of the scale & 825 \\
\hline Cronbach's $\alpha$ value for the flexibility dimension of the scale &, 827 \\
\hline Cronbach's $\alpha$ value for the scale's Response dimension & 869 \\
\hline Cronbach's $\alpha$ value for the Velocity dimension of the scale &, 887 \\
\hline
\end{tabular}

In Table 1 and Table 2, KMO value is greater than 0.5 and $p$ value is less than 0.05 . This shows that the number of samples is sufficient for both scales. Reliability based on alpha coefficients; It is interpreted as not reliable until 0.40 , low as 0.70 , and reliable if greater than 0.70 . In order to test the reliability of the scales, Cronbach's alpha $(\alpha)$ coefficients of both scales were calculated. The fact that these values are higher than 0.70 for both scales and the sub-dimensions of the scales shows that the reliability of the scales is high (see Table 1 and Table 2).

Table-3: Normal Distribution Test Results

\begin{tabular}{|l|l|l|l|l|l|l|l|l|l|l|}
\hline \multirow{2}{*}{ Dimensions } & \multirow{4}{*}{} & \multicolumn{4}{|l|}{ Kolmogorov- Smirnova } & \multicolumn{2}{l|}{ Shapiro-Wilk } & \multicolumn{2}{l|}{ Skewness } & Kurtosis \\
\cline { 3 - 10 } & Number (N) & Statistics & sd & Sig. & Statistics & sd & Sig. & Statistics & Statistics \\
\hline Visionary Leadership & 199 &, 107 & 5 &, 161 &, 958 & 6 &, 277 &,-198 &, 752 \\
\hline Organizational Agility & 199 &, 095 & 6 &, 200 &, 965 & 8 &, 131 &,-243 &, 481 \\
\hline
\end{tabular}

Table 3 shows that the p value of the scales is greater than 0.05 and Skewness and Kurtosis values are between +1 and -1 . Therefore, parametric analysis tests were used in this study. 
Table-4: Demographic Characteristics of Sampling

\begin{tabular}{|c|c|c|c|}
\hline DEMOGRAPHIC VARIABLE & CATEGORY & NUMBER (N) & PERCENT (\%) \\
\hline Age & Under 28 years & 113 & 56.8 \\
\hline (Avg.: 27.95. min-max: 19.00-44.00) & 28 years and older & 86 & 43.2 \\
\hline \multirow[t]{2}{*}{ Gender } & Woman & 127 & 63.8 \\
\hline & Male & 72 & 36.2 \\
\hline \multirow{5}{*}{ Education level } & High school & 61 & 30.7 \\
\hline & Associate & 51 & 25.6 \\
\hline & Bachelors & 64 & 32.2 \\
\hline & Master's Degree & 16 & 8.0 \\
\hline & Doctorate & 7 & 3.5 \\
\hline \multirow{3}{*}{$\begin{array}{l}\text { Duration } \\
\text { of the Institution }\end{array}$} & $1-5$ years & 143 & 71.9 \\
\hline & $6-10$ years & 50 & 25.1 \\
\hline & $11-15$ years & 6 & 3.0 \\
\hline \multirow{3}{*}{$\begin{array}{l}\text { Working Time } \\
\text { with Existing Manager }\end{array}$} & $1-5$ years & 64 & 32.2 \\
\hline & $6-10$ years & 99 & 49.7 \\
\hline & $11-15$ years & 36 & 18.1 \\
\hline \multirow{4}{*}{ Position in the Institution } & Working & 151 & 75.9 \\
\hline & $\begin{array}{l}\text { Lower } \\
\text { Level Manager }\end{array}$ & 25 & 12.6 \\
\hline & Intermediate Manager & 19 & 9.5 \\
\hline & Senior Manager & 4 & 2.0 \\
\hline \multirow{5}{*}{ Position in the Institution } & Doctor & 6 & 3.0 \\
\hline & Nurse & 69 & 24.7 \\
\hline & Health Officer & 31 & 15.6 \\
\hline & $\begin{array}{l}\text { Administrative } \\
\text { Affairs Officer }\end{array}$ & 33 & 16.6 \\
\hline & Other & 60 & 30.2 \\
\hline
\end{tabular}

When table 4 is examined; more than half of the participants were under the age of $28(56.8 \%)$, the majority were female $(63.8 \%)$ and undergraduate graduates $(32.2 \%)$. Most of the participants were those whose working time at the current institution was between 1-5 years (71.9\%) and the current manager and his working time were 6-10 years $(49.7 \%)$. Most of the participants were employees $(75.9 \%)$ and other $(30.2 \%)$ employed persons other than doctors, nurses or civil servants.

Table-5: Descriptive Statistics of Independent and Dependent Variables

\begin{tabular}{|c|c|c|c|c|c|c|}
\hline & Variables & $\begin{array}{l}\text { Number of } \\
\text { Participants }\end{array}$ & Min & Max & Average & $\begin{array}{l}\text { Standard } \\
\text { Deviation }\end{array}$ \\
\hline \multirow{4}{*}{ 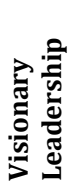 } & Visionary Thinking & 199 & 1,75 & 5,00 & 4,08 & 63 \\
\hline & Action Oriented & 199 & 1,00 & 5,00 & 3,98 &, 62 \\
\hline & Future-Oriented & 199 & 1,67 & 5,00 & 3,90 &, 67 \\
\hline & Innovative & 199 & 2,00 & 5,00 & 4,04 & ,66 \\
\hline \multirow{4}{*}{ 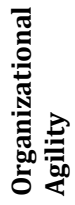 } & Competence & 199 & 2,63 & 5,00 & 4,05 & ,48 \\
\hline & Flexibility & 199 & 2,00 & 5,00 & 4,05 &, 58 \\
\hline & Response Time & 199 & 1,00 & 5,00 & 4,07 & ,61 \\
\hline & Speed & 199 & 2,00 & 5,00 & 4,15 & 61 \\
\hline
\end{tabular}


The average of 5-point Likert scales are interpreted as (Özdamar, 2003):

According to the data in the table, the sub-dimensions of visionary leadership, visionary thinking (avg. 4.08), being action-oriented (avg. = 3.98), being future-oriented $($ avg $=3.90)$, and being innovative $($ avg $=4.04)$. It was concluded that competence (mean $=4.05)$, flexibility $($ mean $=4.05)$, response time $($ mean $=4.07)$ and speed $($ mean $=4.15)$.

Table 6: Correlations Between Variables

\begin{tabular}{|c|c|c|c|c|c|c|c|c|c|}
\hline & Variables & 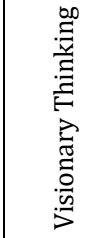 & 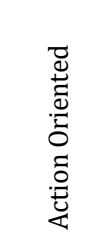 & 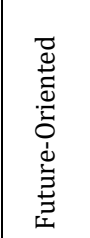 & 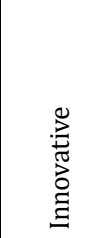 & 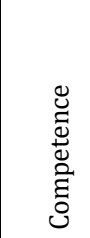 & 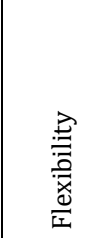 & 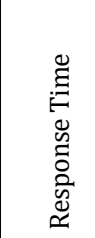 & $\begin{array}{l}\text { Dे } \\
\text { के } \\
\text { की }\end{array}$ \\
\hline \multirow{7}{*}{ 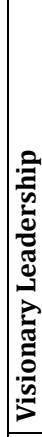 } & Visionary Thinking & 1 & & & & & & & \\
\hline & \multirow[b]{2}{*}{ Action Oriented } & ,638** & \multirow{2}{*}{1} & & & & & & \\
\hline & & ,000 & & & & & & & \\
\hline & \multirow{2}{*}{ Future-Oriented } &, $550^{* *}$ &, $716^{* *}$ & \multirow[b]{2}{*}{1} & & & & & \\
\hline & & ,000 & ,000 & & & & & & \\
\hline & \multirow{2}{*}{ Innovative } &, $639^{* *}$ &, $676^{* *}$ & ,735** & \multirow[t]{2}{*}{1} & & & & \\
\hline & &, 000 &, 000 &, 000 & & & & & \\
\hline & \multirow{2}{*}{ Competence } &, $403^{* *}$ &, $468^{* *}$ &, $406 * *$ &, $437^{* *}$ & \multirow{2}{*}{1} & & & \\
\hline & & ,000 & ,000 & 000 & 000 & & & & \\
\hline & \multirow{2}{*}{ Flexibility } &, $310^{* *}$ &, $380^{* *}$ & , 317** &, $279 * *$ &, $636^{* *}$ & \multirow{2}{*}{1} & & \\
\hline & & ,000 & 000 & ,000 & ,000 & 000 & & & \\
\hline \multirow{4}{*}{ 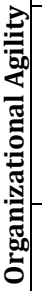 } & \multirow{2}{*}{ Response Time } &, $288^{* *}$ &, $309 * *$ & ,346** & ,299** &, $598^{* *}$ & ,786** & \multirow[t]{2}{*}{1} & \\
\hline & & , 000 & 000 & , 000 & ,000 & , 000 & ,000 & & \\
\hline & \multirow{2}{*}{ Speed } &, $345^{* *}$ & ,389** & ,329** &, $286^{* *}$ & ,643** &, $779^{* *}$ & ,819** & \multirow[t]{2}{*}{1} \\
\hline & & \begin{tabular}{|l|l}
, 000 \\
\end{tabular} & ,000 & 000 & 000 &, 000 & 000 & .000 & \\
\hline
\end{tabular}

Among the dimensions of visionary leadership, the highest relationship was between openness to change and the picture of the future $(r=0.735, p<0.01)$; The highest relationship among organizational agility was found to be between response and speed $(\mathrm{r}=0.819, \mathrm{p}<0.01)$. When the relationship between the sub-dimensions of visionary leadership and the sub-dimension of organizational agility is examined, the highest relationship with which all dimensions are significantly related to each other is 
action-oriented competence ( $\mathrm{r}=0.468, \mathrm{p}<0.01)$, while the lowest relationship is open to change and flexibility dimension ( $\mathrm{r}=0.279, \mathrm{p}<0.01$ ) which is between speed. Furthermore, independent regression analysis to test the hypothesis advanced to reveal explanatory power of the variable on the dependent variable are made.

Table 7: Simple Regression Analysis Result Table of H1 Hypothesis

\begin{tabular}{|l|l|l|l|}
\hline The dependent variable & \multicolumn{3}{|l|}{ Organizational Agility } \\
\cline { 1 - 2 } Independent variable & $\begin{array}{l}\text { Standardized } \\
\text { Beta }(\boldsymbol{\beta})\end{array}$ & t value & Significance level of t value \\
\hline Visionary Leadership & 485 & 7,795 & 000 \\
\cline { 1 - 2 } Adapted R & 232 & \multicolumn{2}{|l}{} \\
\cline { 1 - 2 } & F & 60.775 & \\
\cline { 1 - 2 } F value of significance level & 000 & \multicolumn{2}{|l}{} \\
\hline
\end{tabular}

When the regression results of $\mathrm{H} 1$ hypothesis are examined, it is seen that the $\mathrm{R}^{2}$ value of the regression model is 0,232 . These visionary leadership variables that explain $23.2 \%$ of the variance in the case of organizational agility means.

The effect of visionary leadership on organizational agility was positive and significant $(\beta=0.485 ; \mathrm{p}<, 001)$.

Table-8: Multiple Regression Analysis Result Table of H 2 Hypothesis

\begin{tabular}{|c|c|c|c|}
\hline The dependent variable & Compete & & \\
\hline Independent variable & Beta $(\beta)$ & t value & Significance level of $t$ value \\
\hline Visionary Thinking & 114 & 1,320 & 189 \\
\hline Innovative & ,222 ** & 2,641 & 009 \\
\hline Action-Oriented & ,318 ** & 3,773 & 000 \\
\hline Future-Oriented & 040 & , 391 &, 697 \\
\hline $\mathbf{R}^{2}$ & 238 & & \\
\hline $\mathrm{F}$ & 31.972 & & \\
\hline F value of significance level & 000 & & \\
\hline
\end{tabular}

Table 8 shows how much of the dependent variable (competence) is explained by independent variables (visionary thinking, innovative, action-oriented, futureoriented). Accordingly, $23.8 \%$ of the change in competence can be explained by being open to the changes which are the sub-dimensions of visionary leadership and focus on action. The effect of these dimensions on competence is positive and significant $(\beta=0.222$, $\mathrm{p}<, 001 ; \beta=0.318 ; \mathrm{p}<, 001)$. 
Table-9: Multiple Regression Analysis Result Table of H3 Hypothesis

\begin{tabular}{|c|c|c|c|}
\hline The dependent variable & \multicolumn{3}{|c|}{ Flexibility } \\
\hline Independent variable & Beta $(\beta)$ & t value & Significance level of $t$ value \\
\hline Visionary Thinking & 114 & 1,341 & 182 \\
\hline Innovative & 041 & 458 & 648 \\
\hline Action-Oriented & ,380** & 5.758 & 000 \\
\hline Future-Oriented & 092 &, 972 & 332 \\
\hline $\mathbf{R}^{2}$ & 140 & & \\
\hline $\mathrm{F}$ & 33.155 & & \\
\hline F value of significance level & 000 & & \\
\hline
\end{tabular}

The effect of this dimension on flexibility is positive and significant $(\beta=0.380$, $\mathrm{p}<, 001)$. Visionary thinking was excluded from the model by being open to changes and the effect of formal dimensions of the future on flexibility was not statistically significant $(\mathrm{p}>, 05)$.

Table-10: Multiple Regression Analysis Result Table of H4 Hypothesis

\begin{tabular}{|c|c|c|c|}
\hline The dependent variable & Response & ime & \\
\hline Independent variable & Beta $(\beta)$ & t value & Significance level of $t$ value \\
\hline Visionary Thinking & 140 & 1,763 & ,080 \\
\hline Innovative & ,096 & ,974 & 331 \\
\hline Action-Oriented & 125 & 1,303 & 194 \\
\hline Future-Oriented &, $346^{* *}$ & 5,184 & 000 \\
\hline $\mathbf{R}^{2}$ & 116 & & \\
\hline $\mathrm{F}$ & 26.872 & & \\
\hline F value of significance level & 000 & & \\
\hline
\end{tabular}

The R2 value for the multiple regression model was found to be 116 . According to this, $11.6 \%$ of the change in the response dimension of organizational agility can be explained by the picture of the future, which is the sub-dimension of visionary leadership. The effect of this dimension on response was positive and significant $(\beta=0.346, p<, 001)$. 
Gülay Tamer, "The Effect of Visionary Leadership Characteristics on Organizational Agility in Health Organizations; An Application in Private Hospitals in Bakirkoy District of Istanbul Province", Istanbul Gelisim University Journal of Social Sciences, 8 (2), October 2021, pp. 240-252.

Table-11: Multiple Regression Analysis Result Table of H5 Hypothesis

\begin{tabular}{|c|c|c|c|}
\hline The dependent variable & Speed & & \\
\hline Independent variable & Beta $(\beta)$ & t value & Significance level of $t$ value \\
\hline Visionary Thinking & 163 & 1,928 & 055 \\
\hline Innovative & ,043 & ,483 & 629 \\
\hline Action-Oriented &, $389^{* *}$ & 5.922 & 000 \\
\hline Future-Oriented & 103 & 1,094 & 275 \\
\hline $\mathbf{R}^{2}$ & , 147 & & \\
\hline $\mathrm{F}$ & 35.066 & & \\
\hline F value of significance level & 000 & & \\
\hline
\end{tabular}

The $\mathrm{R}^{2}$ value for the regression model was found to be 147 . According to this; $14.7 \%$ of the change in the speed dimension of organizational agility can be explained by action focus, which is the sub-dimension of visionary leadership. The effect of this dimension on velocity is positive and significant $(\beta=0.389, p<, 001)$. Visionary thinking was excluded from the model by being open to changes and the effect of formal dimensions of the future on speed was not statistically significant $(p>.05)$.

\section{Conclusions and Recommendations for Future Research}

According to the findings of statistical analysis, visionary leadership affects organizational agility. Visionary leaders try to capture the reality of the future based on the existing reality. Not only do they form a vision, but they also predict changes, they become a roadmap for organizations in the process of change and uncertainties. They motivate employees in the framework of vision and change and enable them to focus on business objectives. They also contribute to the development of employees by focusing on the skills and abilities of employees for organizational purposes. They define the goals to be achieved and communicate them to employees through open, verbal and written communication. Thus, employees can clearly understand the meaning and contribution of their work for organizational purposes and become aware of what is expected of them by the leader. As a reflection of these, the organization can achieve agility that can quickly adapt to sudden, unpredictable changes in all environmental and internal factors. Visionary leaders, who believe in the necessity of education and are aware of the power that continuous learning will add to the organizational structure, transfer this thought structure to their subordinates and form an advanced and innovative organization consciousness. This vision of the visionary leaders contributes to the organizations' ability to compete in the current market conditions, to be prepared for the changes and the ability to respond to these changes. The visionary leaders, who continue their activities based on the expectations of the people they serve, contribute to the fact that the organization responds to customer demands and requests in a shorter time compared 
to its competitors and contributes to its being faster than its competitors in the process of preparing products and services.

Companies that want to adapt to the external environment, compete and maintain profitability due to the connections mentioned above should focus on the visionary leadership level of the candidates both in the selection of managers and in the training of managers. It is possible for enterprises acting under the leadership of visionary leaders to increase their level of organizational agility and not to lose their market dominance and not to decrease their profit margins. In the example of company movements mentioned in the literature section, we see that due to the events occurring in the external environment, large companies have closed due to the current management style within the organization and the limited prediction ability of the managers. On the other hand, thanks to the managers who are sensitive to the external environment and prepare the structure within the organization for the situations that may occur before, the companies have achieved great success and today they hold a large share in the market conditions in their fields.

\section{REFERENCES}

AKKAYA, Bülent ve TABAK, Akif. "Örgütsel Çeviklik Ölçeğinin Türkçeye Uyarlanması: Geçerlik ve Güvenirlik Çalışması." İş ve İnsan Dergisi, 2018, 5.2: 185-206.

ARSLAN, 0. (2007)."21st Century Production Approach: Agile Production."

Productivity Journal, 3, pp. 57-70.

AVOLIO, B. J., KAHAI, S. and DODGE, G.E. (2000). "E-leadership: Implications for theory, research, and practice." The Leadership Quarterly, 11.4, pp. 615-668.

BENDER, P. U. (2006). Internal Leadership.' (Translated by Imren Kalyoncu, Fatma Can Akbas). Istanbul: Life Publishing, p.109

CHAN, A. NGAI, E, and MOON, K.L. (2017). "The effects of strategic and manufacturing flexibility and supply chain agility on firm performance in the fashion industry." European Journal of Operational Research,259.2, pp. 486-499.

CLOUD, Y. B. and UYGUN, S.E. (2010). The importance of visionary leadership for effective management: an application on public institutions in Hatay" Mustafa Kemal University Journal of the Institute of Social Sciences, 7.13 pp. 29-47.

ÇAĞLAR, İrfan (2004). "İktisadi ve İdari Bilimler Fakültesi Öğrencileri ile Mühendislik Fakültesi Öğrencilerinin Liderlik Tarzına İlişkin Eğilimlerinin Karşılaștırmalı Analizi ve Çorum Örneği", Ticaret ve Turizm Eğitim Fakültesi Dergisi, Vol 2; 91-107.

GANGULY, A. NILCHIANI, R and FARR, J. V (2009)."Evaluating agility in corporate enterprises." International Journal of Production Economics, 118.2, pp. 410-423.

GOLDMAN, S. L., NAGEL R. N., and PRESSIS, K. (1995). "Agile Competitors and

Virtual Organizations: Strategies for Enriching the Customer," Long Range Plann. vol. 29, p. 131.

KOÇEL, T. (2015). İşletme Yöneticiliği; Yönetim ve Organizasyon Organizasyonlarda Davranış - Klasik, Modern, Çağdaş ve Güncel Yaklaşımlar. Beta Yayınevi.

KOONTZ, H. D. and O’DONNELL, C (1976). “Management, a book of readings”. McGraw-Hill, p. 589.

LONGMAN, (1991). Dictionary of Contemporary English.

MICHAEL, E. and TREVIÑO, L. K. (2006). "Ethical leadership: A review and future directions." The Leadership Quarterly, 17.6, pp.595-661. 
Gülay Tamer, "The Effect of Visionary Leadership Characteristics on Organizational Agility in Health Organizations; An Application in Private Hospitals in Bakirkoy District of Istanbul Province", Istanbul Gelisim University Journal of Social Sciences, 8 (2), October 2021, pp. 240-252. Publishers.

NANUS, B. (1992). “Visionary Leadership”. San, San Fansisco, JosseyBass

NOBARIEIDISHE S. "Impact of organizational agility dimensions on employee's organizational commitment in Foreign Exchange Offices of Tejarat Bank, Iran." European Online Journal of Natural and Social Sciences: Proceedings, 2018, 4.1, p.199.

QUIGLEY, J. V. (1998). "Vizyon Olușturulması Geliștirilmesi ve Korunması", Çev. Berat Çelik, Epsilon Yayınevi, 1. Baskı, İstanbul, pp.279-280.

SHARIFI, $\mathrm{H}$ and ZHENG Z (2007). "A methodology for achieving agility in manufacturing organizations: An introduction." International Journal of Production Economics, 62.1-2.

SHEREHIY, B., KARWOWSKI W and LAYER, J.K. (2007). "A review of enterprise agility: Concepts, frameworks, and attributes", International Journal of Industrial Ergonomics, 37.5 pp.445-460.

TANRIBIL, Sema, "Vizyoner Liderlik Davranışlarının Çalışanların Örgütsel Bağlılık ve Adalet Algılarına Etkisi: Erzurum İli Bankacılık Sektöründe Yapılan Bir Araştırma." Atatürk Üniversitesi Sosyal Bilimler Enstitüsü İșletme Anabilim Dalı Erzurum, 2015. (Yayınlanmamış Yüksek Lisans Tezi).

TETIK, Semra ve AKKAYA, Bülent "Üniversite Gençlerinin Duygu Yönetimi Becerileri Üzerine Bir Araștırma." Sosyal Bilimler Araștırma Dergisi, 2018,7.4, pp.99-121.

TRIAA Wafa, GZAR, Lilia A. and VERJUS, Hervé. "Organizational agility key factors for dynamic business process management." 2018 IEEE 18th Conference on Business Informatics (CBI). Vol. 1. IEEE, 2018.

\section{Özet}

Sağllk Örgütlerinde yönetici ve liderler vizyoner lider özelliklerine sahiptir; Çevresel ve içsel faktörlerdeki ani, öngörülemeyen değişikliklere hızlı uyum sağlamalarına ve yeni gelişmeler doğrultusunda değişen çevre koşullarına uyum sağlamalarına yardımcı olur. Ayrıca sürdürülebilir kalkınma sağlama kabiliyetlerinin düzeyini belirlemek amacıyla yapılan bu çalışmada farklı analiz yöntemleri uygulanmıștır. Çalışmada analizlerden elde edilen neticeler ve bu neticelere ilişkin öneriler sunulmaktadır. İstatistiksel analizlerde yer alan bulgulara göre, vizyoner liderlik örgütsel çevikliği etkilemektedir. Vizyoner liderler mevcut gerçeklikten yola çıkarak geleceğin gerçekliğini yakalama çabası içinde olabilmektedir. Vizyon oluşturmakla kalmaz, değișimleri öngörürler, değişim süreci ve belirsizlikler içindeki örgütler için bir yol haritası olurlar. Çalışanları vizyon ve değişim çerçevesinde motive ederek işletme amaçlarına odaklanmalarını sağlarlar. Ayrıca örgütsel amaçlar için çalışanların beceri ve yeteneklerine odaklanarak gelişimlerine katkıda bulunurlar. İlenecek yol, ulaşılacak hedefleri belirtir ve bunları çalışanlara açık, sözlü ve yazılı iletişim yoluyla aktarırlar. Böylece çalışanlar yaptıkları işin örgütsel amaçlar için anlamını ve katkılarını açıkça anlayabilir, lider tarafından yönlendirmelerle de kendisinden beklenilenlerin farkında olurlar. Bunların bir yansıması olarak örgüt, bütünüyle çevresel ve içsel faktörlerde oluşan ani, öngörülemeyen değişikliklere hızla uyum sağlayabilecek çevikliğe ulaşabilir.

Bu araştırma ile elde edilen sonuçlar doğrultusunda sağlık kuruluşlarında vizyoner liderlerin değişime açık ve eylem odaklı olmaları, çalışanların örgütsel çeviklik becerilerini önemli ölçüde etkilemektedir. Gelecekte karşılaşılabilecek olumlu veya olumsuz durumları araştırarak gerçekçi hedefler belirleyen vizyoner liderler, hizmet verdikleri kişilerin beklentilerini karşılamak için mevcut yetenek ve yetkinliklerini sürekli olarak uyarlayabilir, yenileyebilir ve yeniden yapılandırabilirler. Vizyoner liderliğin alt boyutu olan eylem 
odaklılık, örgütsel çeviklik yeteneklerinden esneklik ile anlamlı olarak etkilemektedir. Örgütün sahip olduğu vizyon dahilinde astlarına belirli sorumluklar yükleyen ve onları sürecin bir parçası kılan vizyoner liderler sergilediği bu liderlik davranışı ile örgütün yapısını ileride meydana gelebilecek değişikliklere hazırlar. Bu sayede gerekli durumlarda örgütün kaynaklarını harekete geçirebilme kabiliyetine katkıda bulunmaktadır. Vizyoner liderlerin sahip oldukları bu görüş örgütlerin mevcut piyasa koşullarında rekabet edebilme gücü kazanmasına, değişimlere hazırlıklı olmasına ve bu değişimlere cevap verebilme yeteneğine katkı sağlamaktadır.

Vizyoner liderliğin alt boyutu eylem odaklıllk olan ile örgütsel çevikliğin alt boyutu olan hız yeteneği arasındaki ilişki pozitif ve anlamlı olarak belirtilmiştir. Hizmet verdiği kimselerin beklentilerini temel alarak çalışmalarını sürdüren vizyoner liderler, örgüt rakiplerine klyasla müşteri talep ve isteklerine daha kısa sürede cevap verebilmesini, ürün ve hizmetlerin hazırlanması sürecinde rakiplerine oranla daha hızl olmasına katkı sağlamaktadır. Dış çevreye uyum sağlamak, rekabet edebilmek ve karlılı̆̆ı sürdürebilmek isteyen işletmeler gerek yönetici seçiminde gerekse yönetici yetiştirme programlarında adayların vizyoner liderlik düzeyine odaklanmalıdır diyebiliriz. Vizyoner liderlerin öncülügünde hareket eden sağlık işletmelerinde ise örgütsel çeviklik düzeylerini arttırarak piyasa hâkimiyetlerinde bir kayba uğramamaları, marka değerlerinde ve hizmet kalitelerinde düşüş yaşamamaları mümkündür. Dış çevreye duyarlı ve örgüt içerisindeki yapıyı daha önceden oluşabilecek durumlara hazırlayan yöneticiler sayesinde örgütler büyük başarılar elde etmiş ve günümüzde kendi alanlarında piyasa koşullarında büyük payı ellerinde tutmaktadır. Sağlık Örgütlerinin çeviklik kazanmasının en verimli yollarından biri sağlık yöneticilerinin seçiminde vizyoner liderlerin ön plana çıkarılmasıdır. 